\title{
Research on the Changes in Japan's Savings Rate
}

\author{
Zhijun Sheng \\ School of Economics and Management \\ Changchun University of Science and Technology \\ Changchun 130022, China \\ Tel: 86-135-0445-7191Ｅ-mail: shengzhijun412@126.com \\ Xiaowei $\mathrm{Mu}$ \\ College of Humanities \& Sciences of Northeast Normal University \\ Changchun 130117, China \\ $\&$ \\ Doctoral student, Economics school, Jilin University, Changchun 130021, China \\ Tel: 86-135-0080-1976_E-mail: mmxxww7643@126.com \\ Accepted: September 10, 2012 \\ Online Published: September 12, 2012 \\ URL: http://dx.doi.org/10.5430/bmr.v1n3p121
}

Received: August 25, 2012

doi:10.5430/bmr.v1n3p121

\begin{abstract}
Japan's savings rate was higher than other countries in the world in the past. However, since 1990s Japan's saving rate has undergone significant changes, which had a downward trend. In order to explain these phenomena, we analyze the determinants of Japan's saving rate, and conclude that income factors, demographic factors and social security system factors have some bad impacts on the saving rate on the basis of the saving theory and analysis of the latest economic data. The changes in Japan's saving rate not only affected its own economies, but also affected the world economy.
\end{abstract}

Keywords: Japan, Saving rate, Determinants, Effect

\section{Introduction}

Japan's savings rate was higher than other countries in the world in the past. In the 1950s and the 1960s, Japan's national savings rate had reached more than $35 \%$, even in the 1980s, Japan's national savings rate has remained above 30\%, far higher than Europe, the United States and other developed countries. (Hayashi, 1986)

In general, Savings are the rest of disposable income for consumption during a period, and the saving rate can be calculated by saving over disposal income. It is the behavior of individuals, a result of the functioning of the economy as a whole. The savings is usually divided into national savings, government savings, corporate savings and household savings. National saving is the sum of the various departments of the country's economy overall savings, including government savings, corporate savings and household savings. The savings rate can measure the level of savings of a country or a region, which may be the proportion of a variety of savings accounts in national income (GDP) or disposable income. Saving rate plays an extremely important role in the economic development of a country.

Since 1990s Japan's saving rate has undergone some significant changes. Japan's saving rate was high until the late 1980 s, but it was decline subsequently and it was low at home and abroad in recent years.(Charles Yuji Horioka, 2009)From the vertical perspective, the national savings rate reached peak of 34.3\% in Japan in 1991, but Japan's saving rate has fallen steadily since 1991 . It is $29.2 \%$ in 1998 and below 30 percent, $22.9 \%$ in 2009 . The Proportion of Japan household income that was used to maintain levels of consumer increased from 1990s. (Yin, 2010) But from the international perspective, Japan's national savings rates is still high among the OECD member countries, the average national savings rate in Japan from 1960 to 2009 has been higher than many countries in the world, but average gap between Japan's saving rate and the OECD is narrowing. It was 10 percentage points more than the OECD in the 1970s, only five percentage points more than the OECD average during the 2000-2009. Compared with 
East Asian countries, Japan's savings rate is lower than many countries since 1990. In the 1990s, the average of Japan's national savings rate was $30.7 \%$ and was lower than the average of China, Singapore, Malaysia, Thailand, Korea and other countries. The average of Japan's national savings rate was $26.6 \%$ during the $2000-2009$, while in China, Singapore, Malaysia, Korea and other countries the average was still higher than $30 \%$.

The continued high savings rate was once credited for its important contribution to the remarkable performance of its "miracle" economies. At the same time, Japan's much saving was output to countries lack of funds, and provide the countries investment needs. Now, the saving rate has declined steadily in Japan since 1990. Therefore this paper will study the reasons savings rate has declined in Japan and considering the effect.

\section{The Determinants of Japan' savings rate}

In this section, we analyze the reasons of saving rate changed in Japan. The changes of Japan's savings rate are affected by economic factors and non-economic factors. However, the thesis is that the most important factors affecting the savings rate in Japan are: income factors, demographic factors and social security factors on the basis of the saving theory and analysis of the latest economic data. The changes in the Japanese income, population and social security system are the key determinants of Japan's changing saving rate. (Mu, 2012)

\subsection{Income factors}

Traditional Keynes's consumption function theory is that as income increased, consumption also will grow, but its growth rate is less than income growth. (Keynes, J.M., 1936) Then, many economists think residents' income is the most important factor affecting residents' savings, such as the theory of Duesenberry's relative income hypothesis, which states that household consumption expenditure often lags behind the changes in income. When income grows, the savings is showed an increase. Of course, if the income level decrease, the consumption is not immediately reduce for people would rather use the savings to maintain the level of consumption who has reached. And now the savings will be reduced. (James S., 1949) Permanent income hypothesis (Friedman, 1957) also revealed a positive correlation between the income and savings. Friedman states that when income increases than expected for a long time, the savings rate may temporarily increase, because people often delay to adjust consumption level. On the other hand, if a decrease of the income with economic stagnation, consumption will make the savings rate reduction because of inertia, which is called "ratchet effect".

Japan's per capita income growth has been a substantial drop than ever before, even negative growth in some years. In 2010 Japanese Ministry of Labor survey shows that the average income in Japan dropped to the lowest point in the past 20 years, and it is expected that the income level will continue to fall. In this case, according to the "ratchet effect", in order to maintain the inertial consumption, people have to spend the savings, so it makes the Japan's savings rate getting lower and lower.

\subsection{Demographic factors}

According to the theory of life cycle, age structure will change the level of savings with the change of population. People have no savings in the juvenile period. However, along with the age growth and income increase, people's level of savings is growing. In the period of elderly, because the savings level of elderly is lower than the level of young people, they start spending their savings after retirement. (Franco, 1988) According to the theory of life cycle, if the proportion of elderly population to the whole population becomes higher, the whole saving rate will fall.

The speed of the aging of Japan's population in the major developed countries is the fastest, the proportion of the population over the age of 65 increased from $7 \%$ in 1970 to $14 \%$ in 1996, it only took 26 years. West Germany and the United Kingdom took 45 years, the United States is expected to take 75 years, Sweden spent 85 years to $14 \%$ in 1975 , France required the longest which had reached $7 \%$ in 1865 , but to $14 \%$ until 2000 , it took 135 years.

While the aging population relying on deposits for a living increases, the elderly will use the previous savings for consumption. Older people's savings rate is negative growth, so that the Japan's population aging would have a downward trend on the saving rate.

\subsection{Social security factors}

According to precautionary savings motive, when the uncertainty of facing balance of payments enhancement about the future, consumers tend to increase current savings to withstand adverse shocks that may be encountered in the future because they have a certain degree of risk aversion. In turn, the improvement of social security system would dispel the worries of the people about the future because it makes the financial risk weakening, so consumers tend to decrease savings. 
Japan constantly improved the social security system and social security spending continued to increase which eliminated the worries of the people, the will of the people to save is not so strongly, the savings rate will decline.

The level of social security was relatively low in Japan until the late 1980s. It was necessary for Japanese residents to save much. The savings was used to prepare for their retirement's life. But the level of social security was greatly improved since the 1990s. The Japanese government provided much financial assistance on social insurance to improve the level of social security.

Japan's social security expenditure as a share of GDP continues to improve, rising from $13.6 \%$ in 1990 to 26.8 in 2009. This proportion is even higher than the United States. After nearly 60 years of reform and development of the social security system in Japan, it has formed a complex and comprehensive system, so social security factors resulted in the decline of the savings rate.

Public old-age pension benefits were relatively low in Japan until 1973. This made it necessary for Japanese households to save on their own to prepare for their life after retirement. But Public old-age pension benefits were dramatically improved in 1973, and a public long-term care insurance program was introduced in 2000. Japan's social security expenditure as a share of GDP continues to improve, rising from $13.6 \%$ in 1990 to $26.8 \%$ in 2009 , this proportion is even higher than the United States. Japan's institutional improvements may enable people to forecast lower risk in the future and alleviate this kind of motive for saving, resulting in the decline of the savings rate.

\section{The effect of the changes in Japan' savings rate}

The purpose of this section is to explore what effect the changes in Japan' savings rate could have on the economy. In the economic growth theories, savings rate occupies an extremely important position. It is an important variable that affects the economic growth rate, because it provides the funds for housing, companies and community etc., the economies can not invest without adequate saving either from domestic, or from abroad.

\subsection{Positive effect}

In a market economy, investment and consumption are the most positive elements of economic growth. The investment demand goes ahead of economic growth, and triggers it for the multiplier effect. But the investment demand is the induced demand rather than the final demand which consumption demand is the core and the most fundamental driving force. The decline of Japan's savings rate corresponds to the increase in domestic consumption rate, conforming to the policy objective of economic reform from export-oriented to demand-oriented. The increase of Japan's consumption rate plays a vital role in promoting economic growth.

\subsection{Negative effect}

The saving is necessary in any economy, which provides money supply to businesses, families and society. So the decline of savings rate may have a negative impact on investment to some extent, further on economic growth, employment and recovery. If Japan's saving is reduced, it may break the investment-saving balance, the current account surplus will decline, and Japan's net domestic saving may disappear. Once it happened, Japan could not only export capital, but also absorb the saving from other countries, which would undoubtedly bring greater negative influence on the world economy, even a shock. Japan even faced the difficult position of "conflicted venture" in past years. (Cheng, 2009)

\subsection{The overall effect}

With the decline of Japan's savings rate, Japanese economy has gone through a recession. Since 1991, average annual growth rate is less than $1 \%$, even a negative growth during a few years, from a creator of the miracle-rapid growth to a loser of indefinitely periods of economic recession. Therefore, we can draw a conclusion that the effect of the adjustments on saving - consumption structure is negative, i.e. the increase in consumption accompanied by the decline of savings rate slows down economic growth.

Why do the changes of Japan's savings rate have an effect? There are two reasons for this phenomenon. One possible reason is that the savings rate is not optimal. According to the Solow-Swan model, the savings rate is not optimal unless it is based on the "golden rule", which maximizes steady state-level or growth of consumption. If the savings rate is too high, it may cause "Dynamic invalid", and vice versa. On the other hand, it is a result of Japan's rapid growth depending heavily on investment and external demand and future overdraft. This also shows that the pattern of growth shifting the reliance on investment to consumption may slow down the economic growth.

\section{Conclusion}

The change of Japan's saving rate in Japan has been very rapid. There are three possible factors that could affect the 
saving rate, which are income factors, demographic factors and social security system factors. Compared with theoretical implications, some data suggest that these elements might have some negative impact on the saving rate of Japan after 1990.

In the economic growth theories, savings rate is an important variable that affects the economic growth rate, because it provides funds for the purchase of plant, equipment, housing and social infrastructure, etc. The decline of Japan's savings rate corresponds to the increase in domestic consumption rate, but the decline of savings rate may have a negative impact on investment to some extent, further on economic growth, employment and recovery. The changes in Japan's saving rate not only affected its own economies, but also affected the world economy.

\section{References}

Charles, Yuji, Horioka. (2009). Past and Future Trends in Japan's Household Saving Rate and the Implications Thereof for Japan's Current Account Balance. [Online] Available: http://rspas.anu.edu.au/economics/tradeandindustry/powerpoints/Trade_Industry_Horioka.pdf

Cheng, Xuezhen, Wang, Ting. (2009). High savings dilemma: Japan's lesson and inspiration, Special Zone Economy, Mar.

Duesenberry, James S. (1949). Income, Savings, and the Theory of Consumer Behavior, Harvard University press.

Hayashi, F. (1986). Why is Japan's saving rate so apparently high?, NBER micro economics Annual Jan.

Keynes, J.M. (1936). The General Theory of Employment, Interest and Money. Macmllan Co.

Modigliani, Franco. (1988). The Role of Intergenerational Transfers and Life Cycle Saving in the Accumulation of Wealth, Journal of Economic Perspectives, Feb. 1988,Spring.

$\mathrm{Mu}$, Xiaowei, Zhang, Yu. (2012). Changes of Japan's Rate and the Implications. Contemporary Economy of Japan, Mar. 2012

Yin, Junhong. (2009). Japan which is the Highest Savings Rates in Industrialized Countries Faces Savings Crisis. [Online] Available: http://big5.ce.cn/cysc/newmain/yc/jsxw/201010/25/t20101025_20530053.shtml 